\title{
Phoxocephalid Amphipod Crustaceans as Predators on Larvae and Juveniles in Marine Soft-Bottom Communities
}

\author{
John S. Oliver, James M. Oakden and Peter N. Slattery \\ Moss Landing Marine Laboratories, Post Office Box 223, Moss Landing, California 95039, USA
}

\begin{abstract}
Feeding patterns of phoxocephalid amphipod crustaceans are explored from soft-bottom communities in Monterey Bay, California (USA), Kaikoura (New Zealand) and McMurdo Sound (Antarctica). Crop contents indicate that benthic invertebrates are major prey, especially soft-bodied nematodes and polychaetous annelids. Phoxocephalids also consume or trample larval and small juvenile polychaetes in laboratory and field feeding experiments. Gut contents of the numerically abundant infaunal species co-occurring with the phoxocephalids (primarily crustaceans and polychaetes) contain few or no invertebrate prey. Dietary patterns and feeding experiments are difficult to link to benthic community structure. Nevertheless, the phoxocephalids may play disproportionately important community roles by consuming settling larvae and juveniles of soft-bodied invertebrates.
\end{abstract}

\section{INTRODUCTION}

The structure of many plant and animal communities may be strongly influenced by the activities of a few species. These foundation species (Dayton, 1975) can play a variety of important functional roles such as mediating competition by preying on competitive dominants (keystone species) (Paine, 1966), furnishing open patches or habitat, and dominating limiting resources. Although disproportionately important species are frequently discussed in marine hard-bottom communities (Paine, 1966, 1974; Dayton, 1971. 1975; Porter, 1972; Lubchenco and Menge, 1978; Glynn et al., 1979), these rock and coral substrates only cover a small fraction of the sea bottom. Most of the ocean floor is covered with soft sediments (sand to mud-sized particles) inhabited by a large number and diversity of small infaunal invertebrates. The numerically abundant soft-bottom macrofauna (sensu Hulings and Gray, 1971; Hessler and Jumars, 1974) are usually much less than $1 \mathrm{~cm}$ in length and are mainly polychaetous annelids, peracarid and other crustaceans, and bivalve molluscs (Sanders, 1960; Barnard, 1963; Lie, 1969; Hessler and Jumars, 1974; Oliver et al., 1980). While there has been recent study of the effects of larger fishes and epifaunal invertebrates on the small infauna (Virnstein, 1977; Bell and Coull, 1978; Woodin, 1978; Hulberg and Oliver, 1980), the biological interactions among small infaunal species are essentially unknown.

Amphipods commonly dominate the number of species and individuals of shallow-water peracarid crustaceans (e.g. Oliver et al., 1980). Although the phoxocephalid amphipods are structurally important members of shallow sand bottoms throughout the Pacific Ocean (Barnard and Drummond, 1978), their natural history is poorly known. Like many amphipods, the phoxocephalids are generally considered detritivores (Enequist, 1949; Biernbaum, 1979). However, feeding observations are rare and their diets remain unquantified. In this paper, we present quantitative information on the diets of several phoxocephalid amphipods and explore their feeding behavior in both laboratory and field experiments. We hypothesize that phoxocephalids are important predators that consume settling invertebrate larvae and small juveniles. If this hypothesis is true, the phoxocephalids may play key functional roles by influencing recruitment and early survival in a variety of soft-bottom communities.

\section{MATERIALS AND METHODS}

Phoxocephalid amphipods were collected from the shallow continental shelf $(<30 \mathrm{~m})$ in 3 geographical regions: Monterey Bay, California $\left(36^{\circ} 48^{\prime} \mathrm{N}\right.$, 
$\left.121^{\circ} 48^{\prime} \mathrm{W}\right)$, Kaikoura, New Zealand $\left(42^{\circ} 25^{\prime} \mathrm{S}, 172^{\circ} 42^{\prime} \mathrm{E}\right)$ and MCMurdo Sound, Antarctica ( $\left.77^{\circ} 49^{\prime} \mathrm{S}, 166^{\circ} 30^{\prime} \mathrm{E}\right)$. Diver-held corers (area $=0.018 \mathrm{~m}^{2}$ ) collected infauna to document population abundance patterns and size structure. Cores were washed over a $.5 \mathrm{~mm}$ screen at all locations and additionally in Antarctica through a $.25 \mathrm{~mm}$ mesh. The smallest amphipods were retained on the $0.5 \mathrm{~mm}$ screen. The $0.25 \mathrm{~mm}$ screen was used to collect the smallest juveniles of the polychaete worms. Residues were preserved in a solution of $4 \%$ formaldehyde. In the Antarctic samples, length plus width of all polychaete individuals was measured. Replicate core samples were collected over time at each location (for details see Oliver, 1980; Oliver et al,, 1980).

Phoxocephalid prey remains were found throughout the gut, but crop contents were easiest to identify and process. Crop contents were placed on slides and examined under a compound microscope and, in many cases, prey were identified to species. Identification was facilitated by polychaete setae and crustacean exoskeletons. Polychaetes and crustaceans were the most abundant macrofaunal groups in each region (Dayton and Oliver, 1977; Oliver et al., 1980; unpubl. data from New Zealand). The crop contents of 7 species of phoxocephalids were examined.

The gut contents of several crustaceans and softbodied infauna that co-occurred with the phox- ocephalids were inspected from California and Antarctica. The isopod Austrosignum grande $(\mathrm{n}=10)$, the cumacean Eudorella spendida $(\mathrm{n}=10)$, the amphipod Monoculodes scabriculosus $(\mathrm{n}=10)$, the tanaid Nototanais dimorphus $(\mathrm{n}=10)$, the polychaetes Spiophanes tcherniai $(n=20)$, Tharyx sp. $(n=20)$, Haploscoloplos kerguelensis $(\mathrm{n}=10)$, Axiothella sp. $(\mathrm{n}=10)$, Myriochele sp. $(\mathrm{n}=10)$, and the anthozoan Edwardsia meridionalis $(\mathrm{n}=200)$ were examined in the Antarctic. The amphipods Eohaustorius spp. ( $\mathrm{n}=20$ ) and the polychaetes Nothria elegans ( $\mathrm{n}=20$ ), Magelona sacculata $(\mathrm{n}=25)$, Amaeana occidentalis $(\mathrm{n}=20)$ and Prionospio spp. $(\mathrm{n}=20)$ were examined in California.

Laboratory feeding experiments were conducted in small dishes (diameter $=5 \mathrm{~cm}$ ) containing mesh walls to retain larvae and juveniles (mesh $=200 \mu \mathrm{m}$ ). Dishes received native sediment devoid of all macrofauna. Each dish was exposed to a steady flow of sea water to insure non-stagnant conditions. Polychaete larvae or early post-larval stages (benthic juveniles) were added to all dishes. Some dishes were set aside as controls. Adult amphipods were added to other dishes at natural densities (except Grandifoxus grandis). In the Antarctic study, the larvae of 2 spionid polychaetes, Nerinides spp. or Nerinopsis sp., were collected by plankton nets and placed in the experimental dishes.

Table 1. Recognizable prey found in the crops of 7 phoxocephalid amphipod species and additional life history information. Each datum is the percentage of phoxocephalids containing a particular prey category (percentages based on non-empty crops)

\begin{tabular}{|c|c|c|c|c|c|c|c|}
\hline Collection periods ${ }^{*}$ & $\begin{array}{c}\text { Grandifoxus } \\
\text { grandis } \\
\text { Aug to Dec }\end{array}$ & $\begin{array}{l}\text { Foxiphalus } \\
\text { obtusidens } \\
\text { Aug to May }\end{array}$ & $\begin{array}{l}\text { Mondibulo- } \\
\text { phoxus gilesi } \\
\text { Aug to Dec }\end{array}$ & $\begin{array}{l}\text { Rhepoxynius } \\
\text { epistomus } \\
\text { Jan, May, } \\
\quad \text { Sep }\end{array}$ & $\begin{array}{l}\text { Rhepoxyaius } \\
\text { daboius } \\
\text { Jan, May. } \\
\text { Sep }\end{array}$ & $\begin{array}{l}\text { McMurdo } \\
\text { Sound } \\
\text { (Antarctica) } \\
\text { Heteropho- } \\
\text { xus videns } \\
\text { Jan to Dec }\end{array}$ & $\begin{array}{l}\text { Kaikoura } \\
\text { (New Zea- } \\
\text { land) } \\
\text { Paraphoxus? } \\
\text { sp. } \\
\text { Jan }\end{array}$ \\
\hline \multicolumn{8}{|l|}{ Prey categories } \\
\hline Annelids & 44 & 42 & 13 & 3 & 10 & 50 & 32 \\
\hline Nematodes & 65 & 42 & 77 & 50 & 10 & 31 & 5 \\
\hline Copepods & 18 & 0 & 13 & 0 & 0 & 31. & 0 \\
\hline Other crustaceans & 3 & 8 & 0 & 0 & 5 & 4 & 5 \\
\hline Other invertebrates & 35 & 0 & 10 & 28 & 15 & 0 & 5 \\
\hline Diatoms, dinoflagelates & 6 & 8 & 7 & 53 & 20 & 54 & 0 \\
\hline \multicolumn{8}{|l|}{ Other information } \\
\hline Number non-empty crops & 34 & 12 & 30 & 32 & $20^{\cdots}$ & 26 & $96 \cdots$ \\
\hline Number crops examined & 38 & 15 & 30 & 34 & 21 & 54 & 27 \\
\hline Length mature female $(\mathrm{mm})$ & 9 & 10 & 5.5 & 3.7 & 3.1 & 6.1 & 5.5 \\
\hline Density $\cdots \mathrm{m}^{-2}(0.5 \mathrm{~mm}$ mesh $)$ & 5 & 10 & 40 & 722 & 970 & 6,468 & 5 \\
\hline Primary depth $(m)$ & intertidal & 6 & 3 & 9 & 14 & 20 & intertidal \\
\hline \multicolumn{8}{|c|}{$\begin{array}{l}\text { - Individuals were examined from all samples with sufficient numbers } \\
\text { - Patches of amphipods often had much higher densities than these average values } \\
\text { - Other full crops contained amorphous detrital material only. If crops were empty, the remaining gut often contained } \\
\text { material }\end{array}$} \\
\hline
\end{tabular}


In California, experiments were conducted with juveniles of the opheliid polychaete Armandia brevis which had been benthic for less than $1 \mathrm{wk}$. Larvae or juvenile survival was monitored after 7 or $10 \mathrm{~d}$. Different experiments were started with different numbers of larvae or juveniles, but treatments and controls received the same number in each experiment. Finally, recruitment experiments were performed in the field, where adults were added to defaunated natural sediment (screened and air-dried) and placed in plastic cups $(10 \times 10 \times 7 \mathrm{~cm})$ in field holding racks. Larval recruitment was compared in sediments with and without adult infauna.

\section{RESULTS}

\section{Crop Contents of Phoxocephalids}

Crop contents of the phoxocephalids from all 3 geographical locations contained whole invertebrate prey as well as macerated parts of diatoms and a variety of small infaunal invertebrates (Table 1). The soft-bodied infauna, especially nematodes and annelids, were the most significant invertebrate prey. The nematodes living in each area were as small as, or smaller than, the common larvae and early post-larval stages of the polychaetes. Oligochaetes were rare at each site (Dayton and Oliver, 1977; Oliver et al, 1980; unpubl. own data from New Zealand). Since the annelid prey were identified by their chitinous setae, their body size could not be measured. Nevertheless, the small size of other abundant prey (nematodes and copepods) suggests that the phoxocephalids probably consume the smaller polychaetes, including settling larvae and juveniles. In addition to diatoms, many crops contained unidentifiable amorphous material that may have been the fleshy remains of prey or detritus. Although only crop contents are reported, similar invertebrate prey, diatoms and amorphous material were observed in the remainder of the gut.

\section{Gut Contents of Other Infauna}

In contrast to the phoxocephalids, gut contents of the other infaunal crustaceans and polychaetes examined from California and Antarctica (see Methods for species and sample sizes) contained no identifiable invertebrate remains. The burrowing anemone Edwardsia meridionalis was the only exception. We found 1 spionid polychaete, 2 tanaids, 2 pelagic polychaetes and 6 calanoid copepods in the guts of 200 E. meridionalis. More than $50 \%$ of these individuals contained diatoms. The polychaetes Spiophanes tcherniai, Magelona sacculata, Amaeana occidentalis and Prionospio spp. were mainly filter feeders as their guts contained little or no sediment and considerable diatoms and detritus. Other species contained sediment, diatoms and amorphous/detrital material. Only a small fraction of the guts of the other infauna were empty.

Table 2. Number of larval and juvenile polychaetes surviving in presence and absence of adult phoxocephalid amphipods in laboratory containers. Treatments without adult amphipods were used as expected value in a Chi-square test for each group of experiments. All Chi-square values are highly significant indicating low survival in the presence of amphipods

\begin{tabular}{|c|c|c|c|}
\hline & $\begin{array}{l}\text { Without adult } \\
\text { amphipods }\end{array}$ & $\begin{array}{l}\text { With adult } \\
\text { amphipods }\end{array}$ & $\begin{array}{l}\text { Chi-square statistic } \\
\text { and significance }\end{array}$ \\
\hline \multicolumn{4}{|c|}{$\begin{array}{l}\text { Heterophoxus videns } \\
\quad(10-\mathrm{d} \text { exposure of Nerinides sp. or Nerinopsis sp. larvae) }\end{array}$} \\
\hline $\begin{array}{ll}\text { Experiment } & 1 \\
\text { Experiment } & 2 \\
\text { Experiment } & 3 \\
\text { Experiment } 4\end{array}$ & $\begin{array}{l}18 \\
18 \\
15 \\
17\end{array}$ & $\begin{array}{l}3 \\
5 \\
7 \\
8\end{array}$ & $X_{3}^{2}=30.3, P<.001$ \\
\hline \multicolumn{4}{|c|}{$\begin{array}{l}\text { Grandifoxus grandis } \\
\text { ( } 7 \text {-d exposure of Armandia brevis juveniles) }\end{array}$} \\
\hline $\begin{array}{ll}\text { Experiment } & 1 \\
\text { Experiment } & 2 \\
\text { Experiment } & 3 \\
\text { Experiment } 4\end{array}$ & $\begin{array}{l}25 \\
37 \\
15 \\
53\end{array}$ & $\begin{array}{r}9 \\
12 \\
2 \\
28\end{array}$ & $\mathrm{X}_{3}^{2}=51.2, \mathrm{P}<.001$ \\
\hline \multicolumn{4}{|c|}{$\begin{array}{l}\text { Rhepoxynius epistomus } \\
\quad(7-\mathrm{d} \text { exposure of } A \text {. brevis juveniles) }\end{array}$} \\
\hline $\begin{array}{ll}\text { Experiment } 1 \\
\text { Experiment } 2\end{array}$ & $\begin{array}{l}16 \\
25\end{array}$ & $\begin{array}{l}9 \\
7\end{array}$ & $\mathrm{X}_{2}^{1}=16, \mathrm{P}<.001$ \\
\hline
\end{tabular}


The infaunal species examined from both California and Antarctica (see Methods) represent the more abundant polychaetes and crustaceans. Gut contents of only 1 abundant crustacean group were not examined in this study (the ostracods of Monterey Bay: Euphilomedes spp.).

A number of relatively large polychaete (own obs.) and nemertean (Roe, 1979) worms consume larger and more mature soft-bodied prey, but their effect on larvae and juveniles is unknown. Unfortunately, these groups were too rare to examine in our study areas.

\section{Feeding Experiments}

Laboratory feeding experiments show that phoxocephalids can eat and trample settling larvae collected from the plankton and benthic juveniles. After $10 \mathrm{~d}$ with the Antarctic amphipod Heterophoxus videns there was a highly significant decrease in the numbers of one or the other of two spionid polychaete larvae when compared to amphipod-free controls (Table 2). Two phoxocephalid amphipods from Monterey Bay, had a similar effect. Grandifoxus grandis and Rhepoxynius epistomus significantly reduced the survival of a juvenile opheliid polychaete during $7-d$ exposures (Table 2). These experimental larvae and juveniles were found in the amphipod guts, and predation events also were witnessed on several occasions.

Field recruitment experiments were more difficult to perform and control. Nonetheless, the few results are consistent with the laboratory feeding experiments. A mixture of Antarctic crustaceans (numerically dominated by Heterophoxus videns and Nototanais dimorphus) caused a significant ( $\mathrm{P}=.001$; Mann-Whitney test) reduction in polychaete larval recruitment into defaunated sediment placed in field holding racks. In Antarctica, $35 \pm 12(\mathrm{n}=9)$ polychaete larvae recruited and survived in control sediments containing no crustaceans, and $10 \pm 5(n=6)$ recruited and survived in sediment containing adult crustaceans (means and $95 \%$ confidence limits). The treatment and control sediments were exposed in the field for 1 yr before collection. Nevertheless, even after 1 yr, the surviving polychaetes in both the amphipod and amphipod-free containers were all small juveniles. Growth rates are extremely slow in these (own obs.) and other Antarctic animals (Dayton et al., 1974; Dayton, 1979). After $7 \mathrm{~d}$ in Monterey Bay, an average of 26 larvae of the polychaete Capitella capitata recruited per cup into control sediments $(n=4)$ containing no amphipods, and only 12 per cup recruited and survived in sediments inhabited by Grandifoxus grandis $(\mathrm{n}=2)$. Efforts to increase replication of these experiments failed because of logistic problems, poor weather and low larval availability.

\section{DISCUSSION}

\section{Predatory Phoxocephalids}

Crop contents indicate that the phoxocephalids consume small infauna that are at least the size of settling polychaete larvae and juveniles. Laboratory feeding experiments and field recruitment experiments provide additional evidence of predation on these early stages. Phoxocephalids have grasping gnathopods, spinose molars and spacious crops (own obs.) that are well suited to a predatory habit and the consumption of soft-bodied prey. Although crop contents and laboratory observations indicate predation, phoxocephalids may also kill larvae and juveniles by trampling or burrowing activities. With the exception of a few individuals of a burrowing anemone, contents of other small infauna co-occurring with the phoxocephalids did not contain invertebrate prey. All these infauna, including the phoxocephalids, contain diatoms and amorphous detrital material. Although the phoxocephalids are capable of deposit feeding, they are unique in containing a large number of invertebrate prey. Our dietary analyses and feeding experiments suggest that the phoxocephalids can influence patterns of recruitment and early survival.

\section{Community Implications}

It is important to link feeding observations and experiments to natural population and community patterns. But these links may not be easy to discover. For example, Segerstråle $(1962,1973)$ argued that Pontoporeia affinis, another burrowing amphipod, had a major effect on population abundance and size structure of the bivalve Macoma baltica. Although Segerstråle did not present dietary information from crop or gut contents, the larvae of another bivalve, Mytilus edulis, were eaten by $P$. affinis in laboratory feeding experiments (Segerstråle, 1962). The primary evidence for predation on young bivalves was a negative correlation between the natural abundances of $P$. affinis and juvenile $M$. baltica in the Baltic Sea.

However, these pattern-matching or correlative arguments commonly neglect likely and realistic alternate explanations (e.g. Dayton and Oliver, 1980; Diamond and Veitch, 1981). Segerstråle did not discuss any of the associated fauna, other biological conditions or physical processes that might confound, influence or produce the relationship between Pontoporeia affinis and Macoma baltica. We found a similar negative relationship between the abundance of the phoxocephalid Heterophoxus videns and the abundances of small species and juveniles of larger species of 
polychaetous annelids in McMurdo Sound, Antarctica (Fig. 1). Although phoxocephalid predation may produce the polychaete pattern, there are other possible explanations. One alternate hypothesis that cannot be falsified at present is that other crustaceans, particularly the tanaid Nototanais dimorphus, consume, trample or chase small, soft-bodied prey The abundance of $N$. dimorphus follows the same trend as the abundance of $H$. videns (Oliver, 1980)

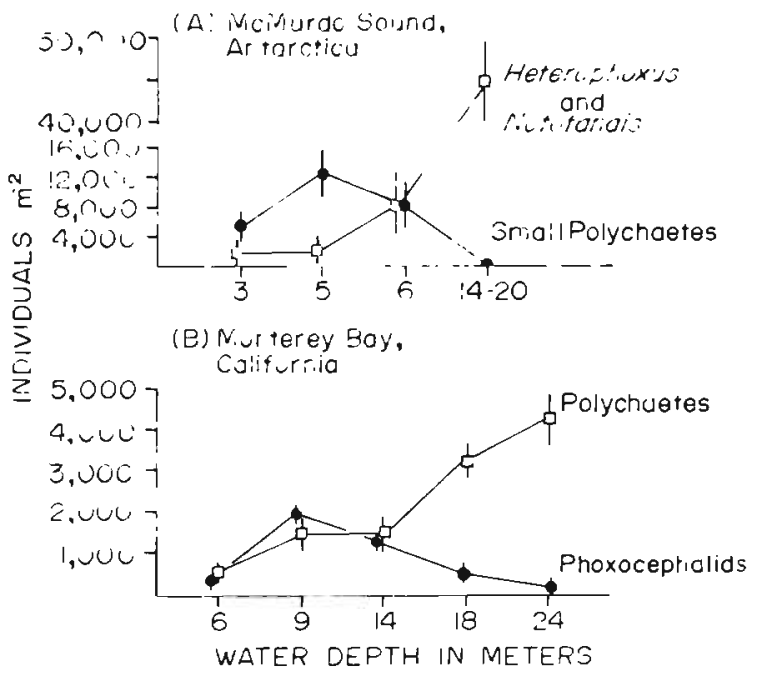

Fig. 1. Depth changes in abundances of 2 crustaceans and small polychaetes in Antarctica (A), and total phoxocephalid and polychaete numbers in California (B). Means and $95 \%$ confidence limits

Similar pattern-matching analyses become more complex in Monterey Bay. Since all the large and small polychaete individuals were not separated, we present the negative relationship between total polychaete and phoxocephalid numbers (Fig. 1). As in McMurdo Sound, other crustacean species show a similar pattern (Oliver et al., 1980) and thus may affect polychaete numbers with the phoxocephalids. Additionally, there are several lines of descriptive-correlative evidence indicating that these same polychaete abundance patterns are strongly influenced by wave-induced bottom disturbance (Oliver et al., 1980). Therefore, although it is important to link our feeding observations and experiments to population and community structure, the links are speculative and fragile at this juncture. Nevertheless, among the small infauna, the predaceous phoxocephalid amphipods may be foundation species in a number of soft-bottom communities.

Acknowledgements. We thank $\mathrm{P}$. Dayton for sharing his insight and enthusiasm. L. Abele, P. Dayton, G. Gillingham, C. Hannan, A. Hurley, C. Jong, C. Peterson, M. Silberstein and $G$. VanBlaricom thoughtfully reviewed an earlier manu- script. R. Hessler was instrumental in stimulating our interest in the interactions among the many small infauna. L. McMasters drew the figures, R. Stelow typed our manuscript and D. Mitchell helped with all aspects of the work. The study was supported by a grant to P. Daton from the NSF Division of Polar Programs and by Moss Landing Marine Laboratories.

\section{LITERATURE CITED}

Barnard, J. L. (1963). Relationship of benthic Amphipoda to invertebrate communities of inshore sublittoral sands of southern California. Pacif. Nat. 3: 439-467

Barnard, J. L., Drummond, M. M. (1978). Gammaridean Amphipoda of Australia, Part III: The Phoxocephalidae. Smithson. Contrib. Zool. 245: 1-551

Bell, S. S., Coull, B. C. (1978). Field evidence that shrimp predation regulates meiofauna. Oecologia 35: 141-148

Biembaum, C. K. (1979). Influence of sedimentary factors on the distribution of benthic amphipods of Fisher's Island Sound, Connecticut. J. exp. mar. Biol. Ecol. 38: 201-223

Dayton, P. K. (1971). Competition, disturbance and community organization: the provision and subsequent utilization of space in a rocky intertidal community. Ecol. Monogr. 41: $351-389$

Dayton, P. K. (1975). Experimental evaluation of ecological dominance in a rocky intertidal algae community. Ecol. Monogr. 45: 137-159

Dayton, P. K. (1979). Observations of growth, dispersal and population dynamics of some sponges in McMurdo Sound, Antarctica. In: Levi, C., Boury-Esnault, N. (eds.) Biologie des Spongaires. Sponge biology: Papers from a colloqium. Editions du centre National de la Recherche scientifigue, Paris, France, pp. 271-282

Dayton, P. K., Robilliard, G. A., Paine, R. T., Dayton, L. B. (1974). Biological accommodation in the benthic community at McMurdo Sound, Antarctica. Ecol. Monogr. 44: $105-128$

Dayton, P. K., Oliver, J. S. (1977). Antarctic soft-bottom benthos in oligotrophic and eutrophic environments. Science, N. Y. 197: 55-58

Dayton, P. K., Oliver, J. S. (1980). An evaluation of experimental analyses of population and community patterns in benthic marine environments. In: Tenore, K. K., Coull, B. C. (eds.) Marine benthic dynamics University of South Carolina Press, pp. 93-120

Diamond, J. M., Veitch, C. R. (1981). Extinctions and introductions in the New Zealand avifauna: cause and effect? Science, N. Y. 211: 499-501

Enequist, P. (1949). Studies on the soft-bottom amphipods of the Skagerak. Zool. Bidr. Upps. 28: 297-492

Glynn, P. W., Wellington, G. M., Birkeland, C. (1979). Coral reef growth in the Galapagos: Limitation by sea urchins. Science, N. Y. 203: 47-49

Hessler, R. R., Jumars, P. A. (1974). Abyssal community analysis from replicate box cores in the central North Pacific. Deep Sea Res. 21: 185-209

Hulberg, L. H., Oliver, J. S. (1980). Caging manipulations in marine soft-bottom communities: importance of animal interactions or sedimentary habitat modifications. Can. J. Fish. Aquat. Sci. 37: 1130-1139

Hulings, N. C., Gray, J. S. (1971). A manual for the study of meiofauna. Smithson. Contrib. Zool. 78: 1-84

Lie, U. (1969). Standing crop of benthic infauna in Puget 
Sound and off the coast of Washington. J. Fish. Res. Bd Can. 26: 55-62

Lubchenco, J., Menge, B. A. (1978). Community development and persistence in a low rocky intertidal zone. Ecol Monogr. 59: 67-94

Oliver, J. S. (1980). Processes affecting the organization of marine soft-bottom communities in Monterey Bay, California and McMurdo Sound, Antarctica. Ph. D. thesis, University of California, San Diego

Oliver, J. S., Slattery, P. N., Hulberg, L. W., Nybakken, J. W. (1980). Relationships between wave disturbance and zonation of benthic invertebrate communities along a subtidal high-energy beach in Monterey Bay, California. Fish. Bull. U. S. 78: $437-454$

Paine, R. T (1966). Food web complexity and species diversity. Am. Nat. 100: 65-75

Paine, R. T (1974). Intertidal community structure: experimental studies on the relationship between a dominant competitor and its principal predator. Oecologia 15: 93-120

Porter, J. W (1972). Predation bay Acanthaster and its effect on coral species diversity. Am. Nat. 106: 487-492
Roe, P. (1979). A comparison of aspects of the biology of Paranemertes peregrina (Nemertea) from Bodega Harbor, California and Washington State. Pacif. Sci. 33: 281-287

Sanders, H. L. (1960). Benthic studies in Buzzards Bay, III: the structure of the soft-bottom community. Limnol. Oceanogr. 5: 138-153

Segerstråle, S. G. (1962). Investigations on Baltic populations of the bivalve Macoma baltica (L.). Part II. What are the reasons for the periodic failure of recruitment and the scarcity of Macoma in the deeper waters of the inner Baltic? Societas Scient. Fenn. Commun. Biolog. 24: 3-26

Segerstråle, S. G. (1973). Results of bottom fauna sampling in certain localities in the Tvarminne area (inner Baltic), with special reference to the so-called Macoma-Pontoporeia theory. Societas Scient. Fenn. Commun. Biolog. 67: $1-12$

Virnstein, R. W. (1977). The importance of predation by crabs and fishes on benthic infauna in Chesapeake Bay. Ecology 58: $1199-1217$

Woodin, S. A. (1978), Refuges, disturbance and community structure: a marine soft-bottom example. Ecology 59: $274-284$ 